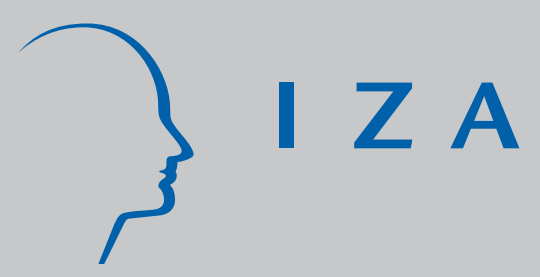

IZADP No. 2774

Human Capital Spillovers and Economic Performance in the Workplace in 2004: Some British Evidence

Renuka Metcalfe

Peter J. Sloane

May 2007 


\title{
Human Capital Spillovers and Economic Performance in the Workplace in 2004: Some British Evidence
}

\author{
Renuka Metcalfe \\ WELMERC, University of Wales Swansea \\ Peter J. Sloane \\ WELMERC, University of Wales Swansea \\ and IZA
}

Discussion Paper No. 2774

May 2007

IZA
P.O. Box 7240
53072 Bonn
Germany

Phone: +49-228-3894-0

Fax: +49-228-3894-180

E-mail: iza@iza.org

\begin{abstract}
Any opinions expressed here are those of the author(s) and not those of the institute. Research disseminated by IZA may include views on policy, but the institute itself takes no institutional policy positions.
\end{abstract}

The Institute for the Study of Labor (IZA) in Bonn is a local and virtual international research center and a place of communication between science, politics and business. IZA is an independent nonprofit company supported by Deutsche Post World Net. The center is associated with the University of Bonn and offers a stimulating research environment through its research networks, research support, and visitors and doctoral programs. IZA engages in (i) original and internationally competitive research in all fields of labor economics, (ii) development of policy concepts, and (iii) dissemination of research results and concepts to the interested public.

IZA Discussion Papers often represent preliminary work and are circulated to encourage discussion. Citation of such a paper should account for its provisional character. A revised version may be available directly from the author. 


\section{ABSTRACT \\ Human Capital Spillovers and Economic Performance in the Workplace in 2004: Some British Evidence ${ }^{*}$}

This paper considers the impact of education and training on both individual and co-worker pay and establishment performance using the matched employer-employee data in WERS 2004, the panel dataset 1998-2004 and the new Financial Performance Questionnaire. This enables us to assess the impact of workplace education and training using both subjective (managers' assessments) and objective data on productivity, profits and establishment survival. We establish that workplace education and training can have positive impacts on establishment financial performance, survival and growth. In contrast to extant studies, it was found that the square and the interaction between own and co-workers years of training also have a positive and significant impact on hourly pay. We find evidence indicating that establishments with $60 \%$ or more of workers trained have a higher establishment performance and also have a powerful impact on the likelihood of establishment survival.

JEL Classification: $\quad$ 12, J4

Keywords: human capital, spillovers, education, training, productivity, profitability, establishment survival

Corresponding author:

Peter J. Sloane

WELMERC, Economics Department

University of Swansea

Singleton Park

Swansea, SA2 8PP

United Kingdom

E-mail: p.j.sloane@swansea.ac.uk

\footnotetext{
* We acknowledge the Department of Trade and Industry, the Economic and Social Research Council, the Advisory, Conciliation and Arbitration Service and the Policy Studies Institute as the originators of the 1998 Workplace Employee Relations Survey data and the 2004 Workplace Employment Relations Survey data, and the Data Archive at the University of Essex as the distributor of the data. The National Centre for Social Research was commissioned to conduct the survey fieldwork on behalf of the sponsors. None of these organisations bears any responsibility for the author's analysis and interpretations of the data.
} 


\section{INTRODUCTION}

It is well known that an individual's human capital has a strong impact on earnings. Relatively few studies, however, have examined the proposition that there are possible externalities arising from the human capital of co-workers within particular establishments through such factors as information sharing, skill complementarity and training by co-workers, particularly in environments emphasising team work. Battu, Belfield and Sloane (2003), using WERS 1998, found that there was a strong and significant effect on own earnings arising from the education of co-workers in addition to the effect of own education. Working with others, each of whom had 12 years (one standard deviation of additional education) would boost own earnings by 11.1 per cent. Or, put another way, an additional year of a single colleague's education is worth about 3.2 per cent of an additional own year of education. Clearly, workers benefit from working in more educated workplaces, but what about the employers? WERS 1998 asked managers whether they considered their establishment to be above average, average or below average in terms of financial performance, labour productivity and product quality. Workplace education had no significant effect on any of these measures of performance, however, suggesting either that workers appropriated all the available economic rents or these subjective answers of managers did not capture these dimensions of performance sufficiently accurately.

WERS 2004 included a new financial performance questionnaire for a sub-sample of establishments covered in the main survey which enables us to test the relationship between workplace human capital and more objective measures of establishment performance. These include sales per worker, value added per worker and profit per worker. Kersley et al. (2006) used these data to mimic the subjective answers provided 
by managers and found though the correlations were positive they were not strong. They go on to suggest that the subjective and objective answers may be measuring different things. There is also substantial panel attrition arising from non-response and missing data. Education is, however, only one form of human capital. Battu, Belfield and Sloane (2004) examined the proposition that similar externalities might apply in the case of training. Whilst no significant effects were found in two low paying service sectors, there were strong positive effects on own earnings elsewhere from increases in mean workplace training. It should be noted also that Dearden, Reed and Van Reenan (2006), using a panel of British industries over the period 1983 to 1996, found that a one percentage point increase in training was associated with an increase in value added per hour of about 0.6 per cent, but an increase in wages of only 0.3 per cent. This suggests that employers do, indeed, capture part of the economic rents arising from investments in training.

Here we utilise WERS 2004 to examine whether similar returns apply to workplace education and workplace training six years after the earlier survey and whether more objective measures of establishment performance reveal a relationship with workplace human capital. It should be noted that whereas WERS 1998 had a cut off of ten employees or establishments to be included in the sample in 2004 this was reduced to 5 employees, so any findings could be influenced by the inclusion of micro firms employing between 5 and 9 employees.

It is possible to link the 2004 Panel with 1998 to assess changes in performance over the period and obtain a subjective evaluation of workplace financial performance over the period. Managers were asked whether their establishment's performance had stayed the 
same, improved or declined since 1998. Further, they were asked to compare the performance of other establishments in their industry or field. Thirty-four per cent of manager's felt performance was above the industry average, 46 per cent about average and 10 per cent below average, while 8 per cent did not answer the question. The Panel can also be used to assess the impact of education and training on establishment survival.

Thus, in addition to the above, we investigate the relationship between previous training and the financial performance and commercial survival of establishments. Since firms pay substantial amounts of money to train employees (Loewenstein and Spletzer, 1998), it is important to examine if these investments are efficacious. If for example, the returns to training are found to be high for a specific group of workers, then policies to encourage training based on this information are clearly warranted.

While there is evidence that training is likely to increase wages (e.g., Vignoles, 2004), productivity and the chances of commercial survival (Collier et al., 2005, 2006), there is little evidence with regard to its influence on recent financial performance. It has been established that increased training of non-manual workers is linked with a greater chance of survival $^{1}$ (Collier et al., 2005 with respect to the 1990-1998 period and Collier et al., $2006^{2}$ with respect to the $1998-2004$ period). In this paper also, we analyse the association between training and establishment survival using the WERS panel of British establishments. 


\section{MODEL SPECIFICATION}

Following Idson and Kahane (2000) we can adapt the human capital model to incorporate the effects of workplace and training and education as below.

$\ln y_{i j}=\alpha_{1}+\alpha_{2} e_{i j}+\alpha_{3} E_{j}+\alpha_{4} e_{i j} * E_{j}+\alpha_{5} t_{i j}+\alpha_{6} T_{j}+\alpha_{7} t_{i j} * T_{j}+\alpha_{8} z_{i j}+\alpha_{9} Z_{j}+v_{j}+u_{i}$

In equation (1), own earnings $y_{\mathrm{ij}}$ are determined by education $e_{\mathrm{ij}}$ of individual $i$ at workplace $j$, the education levels of co-workers $\mathrm{E}_{\mathrm{j}}$ and the interaction between these two education levels. Similar relationships apply to training as suggested by the return to coefficients $\alpha_{5}, \alpha_{6}$ and $\alpha_{7}$. A vector of worker and workplace controls $\mathbf{z}_{\mathrm{ij}}$ and $\mathbf{Z}_{\mathrm{j}}$ are also included $\left[\mathrm{v}_{\mathrm{j}} \sim \mathrm{N}\left(0, \sigma_{\mathrm{j}}\right)\right.$ and $\mathrm{U}_{\mathrm{i}} \sim \mathrm{N}\left(0, \sigma_{\mathrm{i}}\right)$ are identically and independently distributed workplace and individual error terms]. In this specification additional year of an individual workers' own education affects earnings by $\alpha_{2}+\alpha_{4} E_{j}$. The coefficient $\alpha_{2}$ captures the direct impact of years of education, while the coefficient $\alpha_{4}$ captures the impact of average co-worker education on earnings. An additional cross-workplace increase in education of one year will influence earnings directly through the coefficient estimated as $\alpha_{3}$, and indirectly through the interaction coefficient $\alpha_{4}$. If $\alpha_{3}$ is non-zero, then its omission will serve to bias upwards $\alpha_{2}$, the standard measure of the education premium. If $\alpha_{3}$ is positive, own earnings will be positively related to co-workers' education. If $\alpha_{4}$ is positive increased co-workers' education raises wages more for workers with high education levels. Similar relationships also hold for training. Furthermore, the importance of workers being compatible when working together is examined. One approach is to incorporate the absolute mean dispersion of training levels into an earnings equation. Greater dispersion of workplace training, controlling for $t$, should reduce own earnings. As a general test to capture non-linear effects, the square of workplace human capital $\mathrm{T}^{2}$ is included in an earnings equation; if there are increasing 
returns to co-workers' training the coefficient for this parameter will be positive. Similar remarks hold for education.

In summary, the following hypotheses are proposed. First training is rewarded at a relatively higher rate in workplaces where training levels are already high if increasing returns to human capital apply. Second, a greater dispersion of workplace training levels will lower earnings if skills compatibility matters. Similar hypotheses hold for education. We follow Collier et al., 2005 in attempting to establish an association between training and the probability of survival.

\section{DATA AND MEASURES}

To test these hypotheses we use the British Workplace Employment Relations Survey (WERS) 2004 cross-section dataset and the WERS 2004 panel dataset (Department of Trade and Industry, 2005). WERS is a national sample of interviews with managers from 2,295 establishments with at least five workers. The establishment level survey addresses the "management of employees", with information on workforce composition and workplace performance. In addition, up to 25 employees at each workplace were randomly selected for individual survey. This survey asked questions about an individual's education, training, pay and job satisfaction, as well as a range of personal characteristics. The information set is therefore rich, with detailed information on multiple workers per workplace. For estimation, the sample here is restricted to full-time workers and to workplaces where more than three workers responded to the worker survey. This yields information on $13,784^{3}$ workers across 1,651 workplaces. Incorporation of the detailed workplace-level characteristics reduces the information attained to 10,692 workers across 1,295 workplaces. 
With respect to the WERS 2004 panel data and as part of the 2004 WERS, a randomly selected sub-sample of WERS 2004 was re-interviewed ${ }^{4}$. It is this latter information which was utilised to assess the likelihood of the impact of education and training on financial performance directly. Moreover, attempts were made to trace all 2191 workplaces to establish whether these were still viable concerns. This information was utilised to measure workplace survival.

The derivation of the key variables for the matched worker-workplace data is briefly described here; a full derivation is reported in Appendix 1. The simplest way to estimate these relationships is to use years of education as the unit of account (the protocol of using years of education to proxy for human capital skills is followed). First, each worker's full-time equivalent years of education were calculated to obtain $e_{i}$; these calculations were based on reported qualifications. Second, workplace education levels $\mathrm{E}_{\mathrm{j}}$ were derived. Based on the full worker sample (reported by the manager for the entire workforce), mean years of education per occupation are calculated. This mean can then be weighted for each workplace, using information on the occupational mix of the entire workforce at each workplace. Third, the dispersion of workplace education levels is also calculated, where this dispersion measure is the average of absolute differences between own education and mean workplace education. Fourth, pay levels $y_{i j}$ are taken from individual workers' self-reports (across 12 wage bands), and estimated as earnings per hours worked. Median pay across the workplace $\mathrm{Y}_{j}$ is also available; this variable is based on the distribution of pay across the workforce, as reported by the manager. With respect to training, WERS 2004 asks workers how much training they have had during the last 12 months, either paid for or organised by the employer. Only training away from the normal place of work was incorporated, though this could be located on or off the 
premises. A host of answers from none to ten days or more were reported. Any training in the last year (1) or otherwise (0) is the chosen variable. Workplace training was proxied by a variable $\left(\mathrm{T}_{j}\right)$ measuring the percentage of workers trained.

The summary statistics for the matched worker-workplace data are reported in Appendix Table 2. The average years of education per worker are 12.78. Mean education per workplace is 12.75 , and so the sample of respondents has slightly more education than the estimated average of their workplace. The dispersion of education across a workplace is $0.62(\mathrm{SD}, 0.40)$. For the dependent variable, log pay per hour per individual worker is $2.22(\mathrm{SD}, 0.49)$. With respect to training, 67\% of the sample (SD, 0.47) has received training and the corresponding statistic for workplace training is $66 \%$ (SD, 0.33). (The definition of variables with respect to WERS 2004 Panel data is reported in Appendix Table 1).

Such matched worker-workplace data are ideal for testing the first group of hypotheses mentioned above. There are detailed controls for each worker, workplace information from two sources (the manager and the worker respondents) and information on education, training, pay and job satisfaction. This permits numerous sensitivity tests and cross-validation of the results. One potential caveat is that this analysis is based on workplaces, rather than teams: co-worker, in this sense, refers to those in the same workplace, as opposed to those doing the same tasks or team-working. In the absence of the availability of ability controls, however, it is not possible to account for endogenous decisions to accumulate education based on aptitude; in general there is a potential for omitted variable bias. 
We estimate the impact of training on financial performance since 1998 using an ordered probit model, and the determinants of workplace survival using a probit model. We are confronted with a potential omitted variable problem, since the establishment training decision may be endogenous to establishment financial performance and survival. To obviate this problem would necessitate identifying one or more variables which are correlated with training, but not with financial performance and establishment survival. Such instrumental variable selection is often weak or infeasible in the majority of the micro-economic datasets such as this. Therefore, it is not possible to deal with the endogeneity problem here.

\section{ESTIMATION AND RESULTS}

The main hypothesis is whether earnings are increasing in the education and training levels of co-workers. Table 1 reports a series of Mincerian log pay per hour equations, estimated with both own and co-worker levels of education and training. As per equation (1), which includes error terms for workplaces and individuals, random effects generalised least squares is used. (Random effects GLS is a less biased estimator than OLS, since the data are grouped across workplaces (Moulton, 1987). A Hausman test easily rejects the use of fixed effects GLS. All models were also investigated using OLS and fixed effects estimation techniques, but as noted above these are not appropriate estimation techniques, but as noted above these are not appropriate estimation techniques for this dataset (details available upon request). Model (1) includes individual characteristics $\mathbf{z}_{\mathrm{i}}$ only. It shows that an earnings premium for an individual year of education is $6.4 \%$, consistent with the extant literature. This individual-level model of learning explains $33 \%$ of the variation in earnings and the fraction of the variance attributable to the workplace error term $\rho$ is $33 \%$. The provision of training in the 
workplace significantly raises earnings - a worker who has been trained receives $10.4 \%$ more than a worker who has not been trained. Model (2) incorporates firm-level characteristics $\mathbf{Z}$, including industries, workforce composition and size of workplace variables. The premium to education raises slightly to $6.5 \%$, with an increase in the explained variation to $46 \%$; and the workplace error term variance falls to $28 \%$. The training effects on earnings fall slightly. Overall, there are relatively few changes with the inclusion of the firm-level characteristics.

Model (3) incorporates the average years of education across the workplace, $E_{j}$ as an additional workplace-level variable, in conjunction with the provision of training across the workplace. $E_{j}$ is statistically significant and has a strong impact on own earnings. An across-the-workplace increase in education of one year raises earnings by $12 \%$. The premium to own education is reduced slightly. The strength of the $\alpha_{3}$ coefficient suggests that co-worker's education has a strong impact on own earnings. Positive externalities effects are evident. Own training maintains its strong impact on earnings, and spillover effects arising from the training of co-workers is strong. Spillover effects arising from the training of co-workers is evident. Again, the premium to own training is reduced. Coworker's training has a powerful impact on own earnings.

Model (4) is the full estimation specification specified in equation (1), incorporating the interaction between own and co-worker years of education. This interaction term is negative and significant, suggesting for example, an intra-workplace competitive effect. The interaction between own and co-workers training in contrast has a positive and significant impact on earnings, indicating again a 'complementarity' effect or increasing 
returns to scale of human capital. This corroborates the predictions of Idson and Kahane (2000) and Kremer (1993).

Model (5) examines the spread of human capital and training. The square of workplace years of education is reported in conjunction with the square of workplace training. The coefficients on workplace education are positive and significant, but for its square they are negative and significant. This indicates that workplace education boosts own earnings, but at a diminishing rate. Yet, co-worker education boosts own earnings for all meaningful levels of education. With respect to training, the coefficients on workplace training are in contrast negative and significant, but for its square they are positive and significant. The test with respect to education appears to contradict the hypothesis of increasing returns to skill in standardised workplaces, while the test with respect to training seems to conform with the hypothesis of increasing returns to skill in standardised workplaces. In Model (6) a direct measure of dispersion of education is incorporated in place of the interaction term. Adjusting for overall workforce human capital, greater dispersion of education across the workplace has no significant impact on own earnings. Again adjusting for overall workforce human capital, greater dispersion of training across the workplace is associated with lower own earnings. The coefficient of the dispersion of training term is significant at the $1 \%$ level. This corroborates the importance of "standards compatibility" when working in close proximity to one another.

\section{TABLE 1 TO BE INSERTED HERE}




\section{DO EDUCATION AND TRAINING IMPROVE}

\section{ESTABLISHMENT PERFORMANCE?}

First we investigate the impact of training on labour productivity in the private sector as assessed subjectively by managers. Controlling for a number of establishment characteristics it was found that workplace training increases productivity, with the coefficient significant at the $10 \%$ (see Table 2). Apart from workplace training only the variables size and age of establishment are significant. Similarly, it was also found that workplace training increases financial performance significantly at the $5 \%$ level (see Table 3). There is a negative association between labour costs as a proportion of total costs and financial performance. Again younger establishments appear to be more profitable, as are those where team-working is more important. In neither case was mean workplace education significant.

\section{TABLES 2 AND 3 TO BE INSERTED HERE}

We next examine the impact of 1998 training on establishment financial performance over the period 1998 to 2004 using the WERS 2004 panel dataset. The dependent variable is ordered in relation to whether managers stated that financial performance was improving, static or deteriorating. It was found that when $60 \%$ or more of the workers were trained in the previous twelve months, there was a positive and significant impact on establishment performance at the $1 \%$ level. In this case establishment size was significantly and positively related to financial performance.

TABLE 4 TO BE INSERTED HERE 
In addition, we also investigated the effects of training on a range of objective measures of establishment performance, including labour productivity, using the restricted WERS 2004 data from the $\mathrm{ONS}^{5}$. Mean workplace training by occupation is found to have a significant impact on sales (this is a measure of output) per full-time equivalent at the $10 \%$ significant level. See Table 5. This corroborates the results of the ordered probit regressions using the subjective data in Table 2, although the significance level was slightly higher there. Similarly, education was also found to have a significant impact on sales per full-time equivalent at the 5\% level, but only with the exclusion of the union recognition variable (Table 6). In addition, education also had a significant influence on value-added per worker at the $10 \%$ level, with the exclusion of the union recognition and the measure of satisfaction with training variables, and the inclusion of the interaction between training and education (not reported here). We found that it was not possible to find a significant association between education and training and value-added per fulltime equivalent and profit per full-time equivalent, although the signs were positive. The reason for this might include the different perceptions of what managers conceive to be "labour productivity" for example; they might conceive labour productivity to be total factor productivity. But it is not possible due to data constraints to confirm whether or not this is the case. (The education and training coefficients were $0.41(1.28)$ and $0.19(0.38)$ respectively ( $\mathrm{t}$ statistics are in brackets) in the value-added per full-time equivalent equation. The education and training coefficients were 0.60 (1.15) and $0.31(0.36)$ respectively ( $\mathrm{t}$ statistics are in brackets) in the profit/surplus per full-time equivalent equation.)

TABLES 5 AND 6 TO BE INSERTED HERE 
We next include the difference between 2004 and 1998 years as the independent variables, in conjunction with the 1998 training variable and levels of the 1998 employment size, sector and the proportion of workers who work in teams' $\geq 60 \%$ variables to find the impact on establishment financial performance. The dependent variable as before is ordered in relation to whether managers stated that financial performance was improving, static or deteriorating. It appears (Table 7) that training of $60 \%$ or above of the employees at the establishment, has a positive and significant (at the $10 \%$ level) impact on financial performance compared to cases where training was received by less than $60 \%$ of the employees in the workplaces.

\section{TABLE 7 TO BE INSERTED HERE}

Investigating the likelihood of the impact of training on establishment survival using the WERS 2004 panel dataset, it is found that training has a positive and significant impact on establishment survival when $60 \%$ or more workers were trained. Of course, only 1998 independent variables were included for this exercise (see Table 8 for the 1998 year).

\section{TABLE 8 TO BE INSERTED HERE}

\section{CONCLUSIONS}

This analysis of WERS 2004 confirms the presence of human capital spillovers found in earlier studies by Battu et al. (2003, 2004). In addition there is evidence that workplace education and training can have positive impacts on establishment financial performance, survival and growth. The spillovers from workplace education and training on own earnings in the workplace are substantial and independent from the impact of own 
education and training. Unlike the earlier studies it was found that the square of training has a positive and significant impact on hourly pay. In addition, the interaction between own and co-workers years of training also has a positive and significant impact on hourly pay. A greater dispersion of training at the workplace is associated with lower earnings (although, only significant at the $10 \%$ level). This is consistent with the hypothesis of skills compatibility. These spillovers are consistent with a situation in which part of the return to human capital emanates from the interaction of workers with each other as reflected in teamwork or knowledge transferrals.

Using the WERS 2004 restricted objective data on various measures of establishment labour productivity we find that training has a significant impact on sales per full-time equivalent, although only at the $10 \%$ level. Education has a significant impact on sales per full-time equivalent at the 5\% level, with the exclusion of the union recognition variable. In addition, we also find that education has a significant influence on valueadded per worker at the $10 \%$ level with exclusion of the union recognition and the measure of satisfaction with the training received variables and the inclusion of the interaction between workplace education and training variable.

Our analyses using the WERS 2004 panel dataset to investigate establishment performance over time indicate that establishments with $60 \%$ or more of workers trained have a higher establishment performance. Similarly, we find that when $60 \%$ or more of workers are trained there is a powerful impact on the likelihood of establishment survival.

To conclude the evidence of positive effects on performance is stronger for training than education, though there is evidence for a relationship between workplace education and 
productivity when union recognition is not controlled for using objective data. Further research is needed, however, to determine the differences between objective and subjective measures of establishment performance.

\section{TABLE 1}

Log Pay per Hour: Individual and Mean Workplace

Education and Training Levels (GLS random effects)

\begin{tabular}{|c|c|c|c|c|c|c|}
\hline & $\begin{array}{c}{[1]} \\
{[\text { coeff.] }}\end{array}$ & $\begin{array}{c}{[2]} \\
\text { [coeff.] }\end{array}$ & $\begin{array}{c}{[3]} \\
{[\text { coeff. }]}\end{array}$ & $\begin{array}{c}{[4]} \\
{[\text { coeff.] }}\end{array}$ & $\begin{array}{c}{[5]} \\
\text { [coeff.] }\end{array}$ & $\begin{array}{c}{[6]} \\
{[\text { coeff.] }}\end{array}$ \\
\hline $\begin{array}{l}\text { Own years } \\
\text { education } \mathrm{e}_{\mathrm{ij}}\end{array}$ & $0.064(28.48)^{* * *}$ & $0.065(24.92) * * *$ & $\begin{array}{l}0.03 \\
(8.87) * * *\end{array}$ & $\begin{array}{l}0.29 \\
(11.14)^{* * *}\end{array}$ & $0.03(8.94) * * *$ & $0.03(8.87)^{* * *}$ \\
\hline Own training & $0.104(14.94)^{* * *}$ & $0.09(11.48)^{* * *}$ & $\begin{array}{l}0.03 \\
(2.95) * * *\end{array}$ & $\begin{array}{l}-0.10 \\
(-5.03) * * *\end{array}$ & $0.03(3.03)^{* * *}$ & $0.03(3.02)^{* * *}$ \\
\hline \multicolumn{7}{|l|}{ Gender } \\
\hline Male & $0.15(22.31)^{* * *}$ & $0.15(19.69) * * *$ & $\begin{array}{l}0.14 \\
(18.62) * * *\end{array}$ & $\begin{array}{l}0.14 \\
(18.93) * * *\end{array}$ & $\begin{array}{l}0.14 \\
(18.53) * * *\end{array}$ & $\begin{array}{l}0.14 \\
(18.75) * * *\end{array}$ \\
\hline Female & $\begin{array}{l}-0.15 \\
(-22.31) * * *\end{array}$ & $\begin{array}{l}-0.15 \\
(-19.69) * * *\end{array}$ & $\begin{array}{l}-0.14 \\
(-18.62) * * *\end{array}$ & $\begin{array}{l}-0.14 \\
(-18.93) * * *\end{array}$ & $\begin{array}{l}-0.14 \\
(-18.53) * * *\end{array}$ & $\begin{array}{l}-0.14 \\
(18.75)^{* * *}\end{array}$ \\
\hline \multicolumn{7}{|l|}{ Tenure of } \\
\hline 1 to $<2$ years & $0.03(2.78)^{* * *}$ & $0.03(1.97)^{* *}$ & $0.02(1.79)^{*}$ & $0.02(1.82)^{*}$ & $0.02(1.86)^{* *}$ & $0.02(1.74)^{*}$ \\
\hline 2 to $<5$ years & $0.06(5.62)^{* * *}$ & $0.05(4.58) * * *$ & $\begin{array}{l}0.05 \\
(4.43) * * *\end{array}$ & $\begin{array}{l}0.05 \\
(4.54) * * *\end{array}$ & $0.05(4.38) * * *$ & $0.05(4.42)^{* * *}$ \\
\hline 5 to $<10$ years & $0.08(7.03)^{* * *}$ & $0.10(8.24) * * *$ & $\begin{array}{l}0.08 \\
(6.58) * * *\end{array}$ & $\begin{array}{l}0.08 \\
(6.52)^{* * *}\end{array}$ & $0.07(6.19)^{* * *}$ & $0.08(6.63)^{* * *}$ \\
\hline$\geq 10$ years & $0.14(12.38) * * *$ & $0.07(5.92) * * *$ & $\begin{array}{l}0.14 \\
(11.18)^{* * *}\end{array}$ & $\begin{array}{l}0.14 \\
(11.32) * * *\end{array}$ & $\begin{array}{l}0.13 \\
(10.99)^{* * *}\end{array}$ & $\begin{array}{l}0.14 \\
(11.21)^{* * *}\end{array}$ \\
\hline \multicolumn{7}{|l|}{ Age in years } \\
\hline $16-21$ & $\begin{array}{l}-0.29 \\
(-12.91)^{* * *}\end{array}$ & $\begin{array}{l}-0.28 \\
(-11.14)^{* * *}\end{array}$ & $\begin{array}{l}-0.28 \\
(-11.46)^{* * *}\end{array}$ & $\begin{array}{l}-0.28 \\
(-11.50)^{* * *}\end{array}$ & $\begin{array}{l}-0.28 \\
(-11.54)^{* * *}\end{array}$ & $\begin{array}{l}-0.28 \\
(-11.49) * * *\end{array}$ \\
\hline $22-29$ & $\begin{array}{l}-0.07 \\
(-3.94) * * *\end{array}$ & $\begin{array}{l}-0.07 \\
(-3.34) * * *\end{array}$ & $\begin{array}{l}-0.08 \\
(-3.98) * * *\end{array}$ & $\begin{array}{l}-0.09 \\
(-4.28) * * *\end{array}$ & $\begin{array}{l}-0.08 \\
(-4.13) * * *\end{array}$ & $\begin{array}{l}-0.08 \\
(-4.03) * * *\end{array}$ \\
\hline $30-39$ & $0.07(4.22)^{* * *}$ & $0.08(4.02)^{* * *}$ & $\begin{array}{l}0.07 \\
(3.60) * * *\end{array}$ & $\begin{array}{l}0.06 \\
(3.46) * * *\end{array}$ & $0.07(3.49)^{* * *}$ & $0.07(3.54)^{* * *}$ \\
\hline $40-49$ & $0.10(5.81)^{* * *}$ & $0.10(5.45)^{* * *}$ & $\begin{array}{l}0.09 \\
(4.96) * * *\end{array}$ & $\begin{array}{l}0.09 \\
(4.78) * * *\end{array}$ & $0.09(4.76)^{* * *}$ & $0.09(4.94) * * *$ \\
\hline $50-59$ & $0.10(5.71)^{* * *}$ & $0.11(5.58) * * *$ & $\begin{array}{l}0.10 \\
(5.29) * * *\end{array}$ & $\begin{array}{l}0.10 \\
(5.19) * * *\end{array}$ & $0.10(5.12)^{* * *}$ & $0.10(5.29) * * *$ \\
\hline \multicolumn{7}{|l|}{ Ethnicity } \\
\hline British & $0.01(1.11)$ & $0.001(0.54)$ & $0.01(1.26)$ & $0.01(0.90)$ & $0.01(0.63)$ & $0.02(1.29)$ \\
\hline $\begin{array}{l}\text { Work-limiting } \\
\text { disability }\end{array}$ & $\begin{array}{l}-0.07 \\
(-5.17) * * *\end{array}$ & $\begin{array}{l}-0.08 \\
(-4.86) * * *\end{array}$ & $\begin{array}{l}-0.08 \\
(-5.15) * * *\end{array}$ & $\begin{array}{l}-0.08 \\
(-5.00) * * *\end{array}$ & $\begin{array}{l}-0.07 \\
(-4.82) * * *\end{array}$ & $\begin{array}{l}-0.08 \\
(-5.10) * * *\end{array}$ \\
\hline \multicolumn{7}{|l|}{ Employment } \\
\hline Temporary & $-0.04(-1.83)^{*}$ & $\begin{array}{l}-0.05 \\
(-2.22) * * *\end{array}$ & $\begin{array}{l}-0.05 \\
(-2.04) * *\end{array}$ & $\begin{array}{l}-0.04(- \\
1.95)^{* *}\end{array}$ & $-0.05(-2.15)^{* *}$ & $-0.05(-2.03)^{* *}$ \\
\hline Fixed & $-0.02(-1.09)$ & $\begin{array}{l}-0.05 \\
(-2.34) * * *\end{array}$ & $\begin{array}{l}-0.06 \\
(-3.15) * * *\end{array}$ & $\begin{array}{l}-0.06 \\
(-2.95) * * *\end{array}$ & $\begin{array}{l}-0.06 \\
(-2.95)^{* * *}\end{array}$ & $\begin{array}{l}-0.06 \\
(-3.21) * * *\end{array}$ \\
\hline $\begin{array}{l}\text { Overtime or extra } \\
\text { hours worker } \\
\text { whether paid or } \\
\text { unpaid }\end{array}$ & $0.06(10.16)^{* * *}$ & $0.06(8.58)^{* * *}$ & $\begin{array}{l}0.05 \\
(7.49) * * *\end{array}$ & $\begin{array}{l}0.05 \\
(7.36)^{* * *}\end{array}$ & $0.05(7.36)^{* * *}$ & $0.05(7.56)^{* * *}$ \\
\hline
\end{tabular}




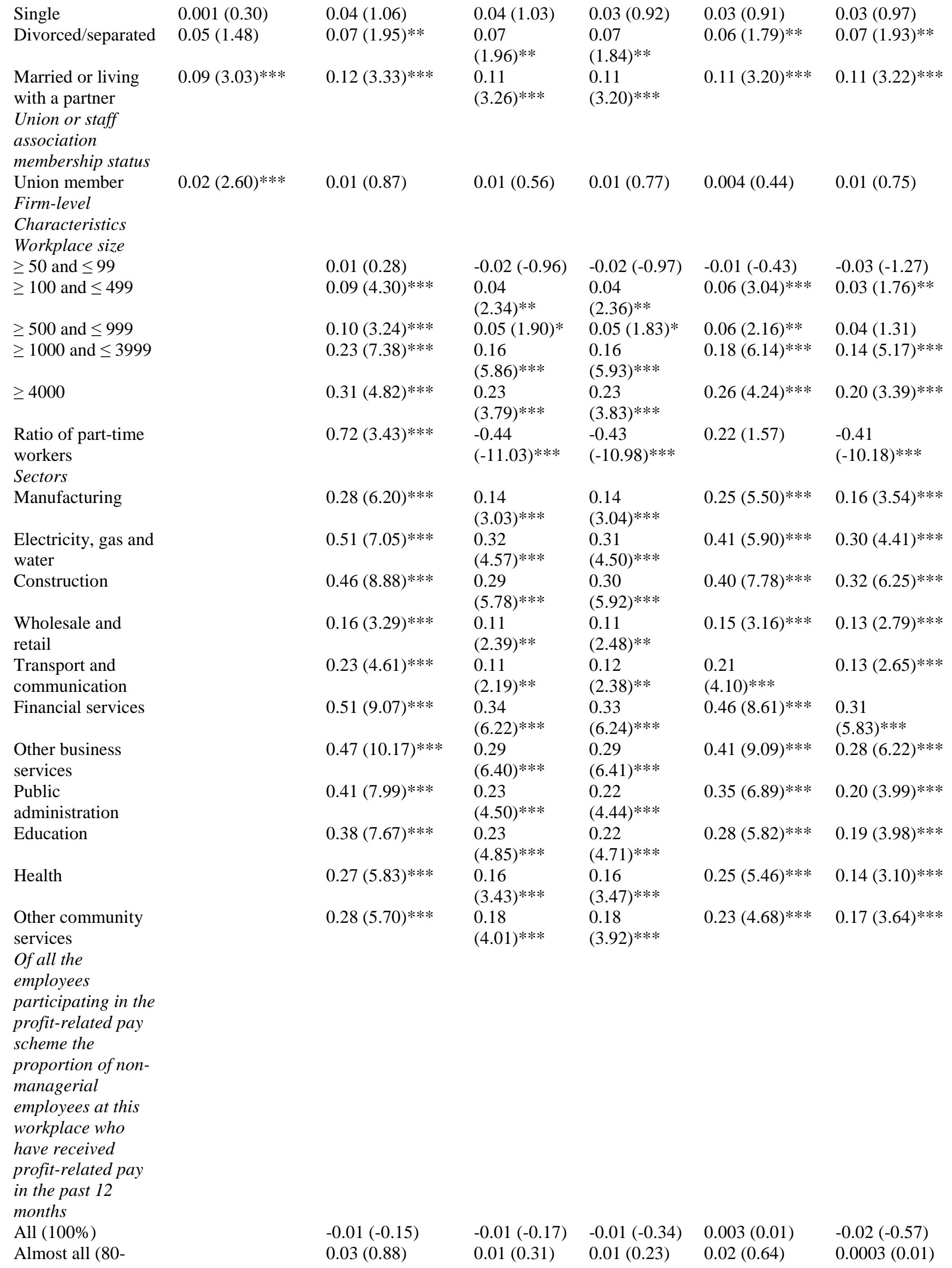


99\%)

Most (60-79\%)

Around half (40-

$59 \%)$

Some (20-39\%)

Few (1-19\%)

Of all the

companies

operating

employee share

schemes for

employees at the

workplace and

employees who are

eligible for it, the

proportion of non-

managerial

employees at this

workplace who

participate in the

employee share

ownership

scheme $(s)$

All (100\%)

Almost all (80-

99\%)

Most (60-79\%)

Around half (40-

$59 \%$ )

Some (20-39\%)

Few (1-19\%)

Ratio of female

Workers

Age of the

workplace

Workplace aged <

20 years

The proportion of

the establishment's

(sales revenuel

operating costs) is accounted for by

wages, salaries and

other labour costs

like pensions and

national insurance

$25 \%-49 \%$

$50-74 \%$

$>75 \%$

During the last 12

months, the number

of employees who

have sustained

injuries

The proportion, if any, of the largest occupational group

$\begin{array}{lllll}-0.01(-0.23) & 0.01(0.15) & 0.002(0.05) & -0.01(-0.12) & -0.01(-0.23) \\ -0.11(-1.23) & -0.02(-0.20) & -0.02(-0.26) & -0.06(-0.69) & -0.01(-0.12) \\ & & & & \\ 0.14(1.52) & 0.11(1.31) & 0.11(1.26) & 0.13(1.43) & 0.10(1.20) \\ -0.15 & -0.14 & -0.15 & -0.15(-1.93) * * & -0.14(-1.97)^{* *} \\ (-1.93) * * * & (-1.94)^{* *} & (-2.03) * * & & \end{array}$

\begin{tabular}{|c|c|c|c|c|}
\hline$-0.01(-0.16)$ & $0.01(0.13)$ & $0.002(0.05)$ & $0.02(0.47)$ & $0.01(0.36)$ \\
\hline $0.03(0.56)$ & $0.03(0.66)$ & $0.03(0.59)$ & $0.05(0.99)$ & $0.04(0.84)$ \\
\hline $0.15(2.16) * *$ & $\begin{array}{l}0.14 \\
(2.09)^{* *}\end{array}$ & $\begin{array}{l}0.13 \\
(2.04) * *\end{array}$ & $0.14(2.05)^{* * *}$ & $0.14(2.18) * *$ \\
\hline$-0.03(-0.41)$ & $0.01(0.12)$ & $0.002(0.05)$ & $0.01(0.16)$ & $0.01(0.25)$ \\
\hline $0.06(0.91)$ & $0.04(0.76)$ & $0.04(0.78)$ & $0.07(1.13)$ & $0.05(0.89)$ \\
\hline$-0.03(-0.47)$ & $-0.01(-0.26)$ & $-0.01(-0.27)$ & $0.01(0.11)$ & $-0.004(-0.08)$ \\
\hline $\begin{array}{l}-0.96 \\
(-3.00) * * *\end{array}$ & $\begin{array}{l}0.08 \\
(1.97) * *\end{array}$ & $\begin{array}{l}0.07 \\
(1.77) * *\end{array}$ & $\begin{array}{l}-0.15 \\
(-4.25) * * *\end{array}$ & $-0.06(-1.48)$ \\
\hline $0.02(1.42)$ & $0.02(1.34)$ & $0.02(1.17)$ & $0.02(1.17)$ & $0.02(1.18)$ \\
\hline
\end{tabular}

$\begin{array}{lllll}0.04(1.70)^{*} & 0.03(1.40) & 0.03(1.34) & 0.04(1.75)^{*} & 0.03(1.72)^{*} \\ -0.001(-0.01) & 0.01(0.29) & 0.01(0.28) & 0.01(0.40) & 0.01(0.57) \\ 0.06(2.44)^{* *} & 0.05 & 0.05 & 0.05(2.01)^{* *} & 0.05(2.17)^{* *} \\ & (2.18)^{* *} & (2.15)^{* *} & & \\ -0.08 & -0.07 & -0.07 & -0.07 & -0.06 \\ (-4.40)^{* * *} & (-3.96)^{* * *} & (-3.89)^{* * *} & (-3.99)^{* * *} & (-3.550)^{* * *}\end{array}$


at this workplace who work in teams $\geq 60 \%$ $0.06(3.52) * * *$

$\begin{array}{llll}0.03 & 0.03(1.81)^{*} & 0.04(2.37)^{* *} & 0.02(1.30)^{*} \\ (1.94)^{* *} & & & \\ 0.12 & 0.38 & 0.77 & 0.11 \\ (22.23)^{* * *} & (14.48)^{* * *} & (11.76)^{* * *} & (20.46)^{* * * *} \\ 0.18 & 0.06 & -0.17 & 0.17 \\ (11.42)^{* * *} & (2.83)^{* * *} & (-3.80)^{* * *} & (10.85)^{* * * *} \\ & -0.02 & & \\ & (-10.17)^{* * *} & \\ & 0.22 & \\ & (7.31)^{* * *} & & \\ & & -0.02 & \\ & & (-9.98)^{* * *} & \\ & & 0.32(8.37)^{* * *}\end{array}$

Squared term:

training

Dispersion of $E_{j}$

Dispersion of $\mathrm{T}_{\mathrm{j}}$

$0.14(7.09)^{* * *}$

$-0.18$

$\mathrm{R}^{2}$

0.33

0.46

0.55

0.56

$(-3.54) * * *$

$\rho_{\mathrm{j}} \mathrm{N}_{\mathrm{j}}\left[\mathrm{N}_{\mathrm{i}}\right]$

0.33

0.28

0.26

0.26

0.56

$1,660[14,665]$

$1,303[11395]$

Notes: $\mathrm{z}$ statistics are in parentheses. $* * *=1 \%$ level, $* *=5 \%$ level, $*=10 \%$ level. This notation for denoting significance levels applies to all succeeding Tables.

The omitted categories in each variable group are as follows:

Tenure of: $<1$ year

Age in years: $\geq 60$ years

Ethnicity: Non-British

Employment: Permanent

Marital status: Widowed

Union or staff association membership status: Non-union member

Firm-level Characteristics:

Workplace size: $<50$

Sectors: Hotels and Restaurants

Of all the employees participating in the profit-related pay scheme the proportion of non-managerial employees at this workplace who have received profit-related pay in the past 12 months: None $(0 \%)$

Of all the companies operating employee share schemes for employees at the workplace and employees who are eligible for it, the proportion of non-managerial employees at this workplace who participate in the employee share ownership scheme(s): None (0\%)

Age of the workplace: Workplace aged $>20$ years

The proportion of the establishment's (sales revenue/operating costs) is accounted for by wages, salaries and other labour costs like pensions and national insurance: $<25 \%$

During the last 12 months, the number of employees who have sustained injuries: No injuries

The proportion, if any, of the largest occupational group at this workplace who work in teams: $<60 \%$. 


\section{TABLE 2}

\section{Labour Productivity: Subjective Estimates of the Impact}

of Workplace Education and Training (Ordered Probit)

Workplace size

$<50$

$0.32(1.87)^{*}$

$\geq 50$ and $\leq 99$

$0.42(3.34)^{* *}$

$\geq 100$ and $\leq 499$

$0.23(1.45)$

$\geq 500$ and $\leq 999$

$0.21(1.08)$

$\geq 4000$

Ratio of part-time workers

$1.06(1.47)$

Sectors

Manufacturing

$-0.16(-0.82)$

Electricity, gas and water

$-0.002(-0.01)$

Construction

$0.19(0.17)$

Hotels and Restaurants

$-0.02(-0.09)$

Transport and communication

$0.21(1.25)$

Financial services

$0.02(0.12)$

$0.01(0.05)$

Other business services

$0.11(0.69)$

Public administration

$-0.10(-0.33)$

Education

$-0.03(-0.10)$

Health

$0.13(0.74)$

Other community services

$0.13(0.74)$

Of all the companies operating employee share schemes for employees at the workplace

$0.14(1.43)$

and employees who are eligible for it, the proportion of non-managerial employees

at this workplace who participate in the employee share ownership scheme(s)

Ratio of female Workers

Workplace aged $<20$ years

The proportion of the establishment's (sales revenue/operating costs) is accounted for by wages, salaries and other labour costs like pensions and national insurance $25 \%-49 \%$

$50-74 \%$

$-0.06(-0.58)$

$>75 \%$

$-0.18(-1.51)$

$-0.03(-0.21)$

During the last 12 months, the number of employees who have sustained injuries

$-0.01(-0.12)$

The proportion, if any, of the largest occupational group at this workplace work in teams $\geq 60 \%$

Mean workplace education

Mean workplace training

Log pseudolikelihood

Notes: $\mathrm{z}$ statistics are in parentheses.

The omitted categories in each variable group are the same as in Table 1 with the exception of:

Workplace size: $\geq 1000$ and $\leq 3999$

Sectors: Wholesale and retail 


\section{TABLE 3}

\section{Financial Performance: Subjective Estimates of the Impact of Workplace Education and Training (Ordered Probit)}

Workplace size

$<50$

$0.03(0.17)$

$\geq 50$ and $\leq 99$

$0.25(1.15)$

$\geq 100$ and $\leq 499$

$0.09(0.44)$

$\geq 500$ and $\leq 999$

$0.31(1.31)$

$\geq 4000$

Ratio of part-time workers

$0.49(1.10)$

Sectors

Manufacturing

$-0.23(-1.18)$

Electricity, gas and water

$0.03(0.19)$

$0.23(0.84)$

Construction

$0.27(1.56)$

Hotels and Restaurants

Transport and communication

$0.45(2.85)^{* * * *}$

Financial services

$0.12(0.63)$

Other business services

$0.40(2.18)^{* *}$

$0.13(0.87)$

Public administration

$0.27(1.00)$

Education

$0.41(1.45)$

Health

Other community services

Of all the companies operating employee share schemes for employees at the

$0.10(0.55)$

$-0.04(-0.25)$

workplace and employees who are eligible for it, the proportion of non-managerial

employees at this workplace who participate in the employee share ownership scheme(s)

$0.11(1.12)$

Ratio of female Workers

Workplace aged $<20$ years

$0.24(1.24)$

$0.17(2.29)^{* *}$

The proportion of the establishment's (sales revenue/operating costs) is accounted for

by wages, salaries and other labour costs like pensions and national insurance

$25 \%-49 \%$

$50-74 \%$

$>75 \%$

During the last 12 months, the number of employees who have sustained injuries

The proportion, if any, of the largest occupational group at this workplace work in teams $\geq 60 \%$

Mean workplace education

Mean workplace training

Pseudo $\mathrm{R}^{2}$

Log pseudolikelihood

Prob $>\mathrm{chi}^{2}$

$-0.33(-3.63)^{* * * *}$

$-0.33(-2.95) * * *$

$-0.45(-2.90) * * *$

$0.11(1.19)$

$0.14(1.80)^{*}$

$-0.03(-1.06)$

$0.32(2.08)^{* *}$

0.03

$-1098.781$

0.0000

$\mathrm{N}_{\mathrm{j}}$

915

Notes: z statistics are in parentheses.

The reference categories in each variable group are the same as in Table 2. 


\section{TABLE 4}

Impact of Training on Financial Performance over Time with 2004 year Explanatory Variables with the exception of the 1998 year Training Variable (Ordered Probit estimates)

$\geq 60$ of experienced workers have been in receipt of off-the-job training over the past 12

months

Workplace size

$<50$

$0.29(1.44)$

$\geq 50$ and $\leq 99$

$0.39(1.79)^{*}$

$\geq 100$ and $\leq 499$

$0.42(2.07)^{* *}$

$\geq 500$ and $\leq 999$

$0.60(2.43)^{* *}$

$\geq 4000$

$0.74(1.90)^{*}$

Sectors

Manufacturing

$0.05(0.25)$

Electricity, gas and water

$-0.12(-0.45)$

Construction

$0.34(1.43)$

Wholesale and Retail

$0.28(1.33)$

Hotels and Restaurants

$0.35(1.54)$

Transport and communication

$-0.36(-1.38)$

Financial services

$0.50(1.76)^{*}$

Public administration

$0.19(0.84)$

Education

$-0.05(-0.26)$

Health

$0.05(0.29)$

Other community services

$0.07(0.29)$

Workplace aged $\geq 20$ years

$0.18(1.80)^{*}$

The proportion, if any, of the largest occupational group at this workplace work in teams $\geq 60 \%$

Pseudo $\mathrm{R}^{2}$

$-0.11(-0.94)$

0.03

Log pseudolikelihood

$-541.84$

Prob $>$ chi $^{2}$

0.0176

$\mathrm{N}_{\mathrm{j}}$

601

Source: ONS

Notes: z statistics are in parentheses.

Financial Performance since 1998

The reference categories in each variable group are the same as in Tables 2 and 3 with the exception of:

The proportion of experienced workers who have been in receipt of off-the-job training over the past 12 months: < $60 \%$

Sectors: Other business services

Age of the workplace: Workplace aged $<20$ years. 


\section{TABLE 5}

\section{Objective Estimates of the Impact of Workplace Education and Training on Labour Productivity (Sales per full-time equivalent) \\ Dependent variable: Sales per full-time equivalent}

Workplace size

$0.71(0.78)$

$<50$

$0.20(0.23)$

$\geq 50$ and $\leq 99$

$0.61(0.75)$

$\geq 100$ and $\leq 499$

$0.62(0.75)$

$\geq 500$ and $\leq 999$

$0.71(1.02)$

$\geq 1000$ and $\leq 3999$

$1.10(1.06)$

Sectors

Manufacturing

$-0.22(-0.42)$

Electricity, gas and water

$0.68(0.63)$

Wholesale and retail $-0.07(-0.12)$

Hotels and Restaurants

$0.84(0.67)$

Transport and communication

$-1.12(-1.33)$

Financial services

$0.27(0.40)$

Other business services

$-0.60(-0.98)$

Education

$-0.86(-1.05)$

Health

$-0.68(-0.52)$

Other community services

$-0.94(-1.42)$

Of all the companies operating payment by results or merit, the proportion of non-manager employees who are the recipient either of these

$100 \%$

$80-99 \%$

$-0.002(0.00)$

$60-79 \%$

$1.59(2.10)^{* *}$

$40-59 \%$

$0.55(0.89)$

$20-39 \%$

$0.57(1.04)$

$1-19 \%$

$0.41(0.76)$

Of all the companies operating employee share schemes for employees at the workplace

$-0.01(-0.02)$

and employees who are eligible for it, the proportion of non-managerial employees

at this workplace who participate in the employee share ownership scheme(s)

Ratio of female Workers

Workplace aged > 20 years

$-0.28(-0.84)$

The proportion of the establishment's (sales revenueloperating costs) is accounted for by wages, salaries and other labour costs like pensions and national insurance

$25 \%-49 \%$

$50-74 \%$

$>75 \%$

During the last 12 months, the number of employees who have sustained injuries

The proportion, if any, of the largest occupational group at this workplace work in teams $\geq 60 \%$

Assessment of the degree of competition in the trading sector and those trading externally Very High

High

Neither

$-0.17(-0.59)$

$-0.26(-0.66)$

$-0.94(-1.67) *$

$0.40(-1.32)$

Low

Number of competitors for the main product or service in the trading sector and those trading externally

Few Competitors

Many Competitors

Current State of the market in which you operate (for your main product or service) in the trading sector and those trading externally 
The market is growing

The market is declining

The market is turbulent

Union Recognition

$-0.64(-1.79)^{*}$
$0.32(0.55)$

$\geq 1$ union recognised by management for negotiating pay and conditions

Bargaining coverage

$0.32(0.55)$

Description of Ownership of those establishments in the private sector

UK owned/controlled

$-1.29(-2.03)^{* *}$

Predominantly UK owned (51\% or more)

$-0.99(-1.21)$

Predominantly foreign owned (51\% or more)

$-0.53(-0.70)$

Foreign owned/controlled

$-1.20(-1.67)^{*}$

Additional Establishment and organisation characteristics

$-0.68(-1.03)$

One of a number of different workplaces in the UK belonging to the same organisation

Single independent establishment not belonging to another body

$-0.58(-0.90)$

ining received

Very satisfied and satisfied with the training received

$-0.98(-1.24)$

Mean workplace education

$0.45(1.43)$

Mean workplace training

$0.90(1.64)^{*}$

$\mathrm{R}^{2}$

0.39

$\mathrm{F}(50,129)$

2.34

Prob > F

0.0001

$\mathrm{N}$

180

Source: ONS

Notes: $t$ statistics are in parentheses.

The omitted categories in each variable group are the same as in Tables 2 and 3 with the exception of:

Sectors: Wholesale and retail; (Public Administration inapplicable as we are only considering private sector workplaces)

Of all the companies operating payment by results or merit, the proportion of non-managerial employees

who are the recipient either of these: None

Age of the workplace: Workplace aged $<20$ years

Assessment of the degree of competition in the trading sector and those trading externally: very low

Number of competitors for the main product or service in the trading sector and those trading externally: None

Union Recognition: None

Bargaining coverage: None

Description of Ownership of those establishments in the private sector: UK and foreign owned

Additional Establishment and organisation characteristics: Sole UK establishment of a foreign organisation

Employees Satisfaction with training received: Not very satisfied or satisfied. 


\section{TABLE 6}

\section{Objective Estimates of the Impact of Workplace Education and Training on Labour Productivity (Sales per full-time equivalent) \\ Dependent variable: Sales per full-time equivalent (Independent Variables exclude Union Recognition)}

Workplace size

$<50$

$1.04(1.08)$

$\geq 50$ and $\leq 99$

$0.54(0.58)$

$\geq 100$ and $\leq 499$

$0.86(0.98)$

$\geq 500$ and $\leq 999$

$0.79(0.86)$

$\geq 1000$ and $\leq 3999$

$0.68(0.89)$

Ratio of part-time workers

Sectors

Manufacturing

$-0.35(-0.68)$

Electricity, gas and water

$0.34(0.32)$

Wholesale and retail

$0.06(0.11)$

Hotels and Restaurants

$0.48(0.43)$

Transport and communication

$-1.07(-1.40)$

Financial services

$0.14(0.21)$

Other business services

$-0.67(-1.16)$

Education

$-1.17(-1.42)$

Health

$-0.77(-0.58)$

Other community services

$-0.94(-1.38)$

Of all the companies operating payment by results or merit, the proportion of non-manager employees who are the recipient either of these

$100 \%$

$0.17(0.35)$

$80-99 \%$

$1.56(2.05)^{* *}$

$60-79 \%$

$0.69(1.15)$

$40-59 \%$

$0.69(1.29)$

20-39\%

$0.44(0.81)$

$1-19 \%$

$-0.05(-0.08)$

Of all the companies operating employee share schemes for employees at the workplace

$-0.22(-0.69)$

and employees who are eligible for it, the proportion of non-managerial employees

at this workplace who participate in the employee share ownership scheme(s)

Ratio of female Workers

Workplace aged > 20 years

$-0.72(-0.92)$

The proportion of the establishment's (sales revenueloperating costs) is accounted for by wages, salaries and other labour costs like pensions and national insurance $25 \%-49 \%$

$0.05(0.15)$

$50-74 \%$

$>75 \%$

During the last 12 months, the number of employees who have sustained injuries

The proportion, if any, of the largest occupational group at this workplace work in teams $\geq 60 \%$

Assessment of the degree of competition in the trading sector and those trading externally Very High

High

Neither

Low

Number of competitors for the main product or service in the trading sector and those trading externally

Few Competitors

Many Competitors

Current State of the market in which you operate (for your main product or service) in the 
trading sector and those trading externally

The market is growing

$0.26(0.46)$

The market is declining

$-0.17(-0.36)$

The market is turbulent

$-0.37(-0.89)$

Bargaining coverage

$0.05(0.11)$

Description of Ownership of those establishments in the private sector

UK owned/controlled

Predominantly UK owned (51\% or more)

$-1.18(-1.96)^{* *}$

$-0.81(-1.00)$

Predominantly foreign owned (51\% or more)

$-0.57(-0.81)$

Foreign owned/controlled

Additional Establishment and organisation characteristics

One of a number of different workplaces in the UK belonging to the same organisation

$-0.84(-1.30)$

Single independent establishment not belonging to another body

Employees Satisfaction with training received

Very satisfied and satisfied with the training received

$-0.94(-1.18)$

Mean workplace education

$0.58(2.03)^{* *}$

Mean workplace training

$\mathrm{R}^{2}$

37

$\mathrm{F}(49,133)$

2.40

Prob > F

0.0000

$\mathrm{N}$

Source: ONS

Notes: $\mathrm{t}$ statistics are in parentheses.

The reference categories in each variable group are the same as in Table 5.

\section{TABLE 7}

Impact of training on Financial Performance over Time using the 1998 year Training Independent Variable and Changes and Levels of Independent variables (Ordered Probit Estimates)

$\geq 60$ of experienced workers have been in receipt of off-the-job training over the past 12 months

Workplace size

$<50$

$\geq 50$ and $\leq 99$

$\geq 100$ and $\leq 499$

$\geq 500$ and $\leq 999$

$\geq 4000$

Proportionate change in Workplace size

Sectors

Manufacturing

Electricity, gas and water

Construction

Wholesale and Retail

Hotels and Restaurants

Transport and communication

Financial services

Public administration

Education

Health

Other community services
[1]

[coeff.]

$0.17(1.65)^{*}$

$0.32(1.54)$

$0.23(1.03)$

$0.38(1.86)^{*}$

$0.29(1.14)$

$0.47(0.63)$

$0.001(1.66)^{*}$

$0.35(1.82)^{*}$

$0.18(0.63)$

$0.39(1.63)^{*}$

$0.27(1.30)^{* *}$

$0.68(2.46)^{* * *}$

$0.08(0.27)$

$0.90(3.29)^{* * *}$

$0.31(1.50)$

$0.25(1.38)$

$0.11(0.62)$

$0.61(2.18)^{* *}$ 
Proportionate change in Sectors

$-0.09(-0.87)$

Proportionate change in $\geq 60 \%$ team working of the

largest occupational group at this workplace

Pseudo $\mathrm{R}^{2}$

Log pseudolikelihood

$-493.165$

Prob > chi2

0.1804

$\mathrm{N}_{\mathrm{j}}$

538

Notes: z statistics are in parentheses.

The reference categories are the same as Table 4 with the exception of the workplace age, since its inclusion is meaningless. The reference category for the proportion of experienced workers being in receipt of off-the-job training over the past 12 months: < $60 \%$.

\section{TABLE 8}

\section{Impact of Training on Establishment Survival using only 1998 year Independent variables (Probit estimates)}

$\geq 60$ of experienced workers have been in receipt of off-the-job training over the past

12 months

Workplace size

$<50$

$-0.54(-2.73) * * *$

$\geq 50$ and $\leq 99$

$-0.16(-0.76)$

$\geq 100$ and $\leq 499$

$-0.20(-1.00)$

$\geq 500$ and $\leq 999$

$-0.12(-0.50)$

$\geq 4000$

$-0.16(-0.25)$

Sectors

Manufacturing

$-0.94(-4.30) * * *$

Electricity, gas and water

$-1.11(-4.28) * * *$

Construction

Wholesale and Retail

$-0.66(-2.65) * * *$

$-0.55(-2.50) * * *$

Hotels and Restaurants

$-0.35(-1.36)$

Transport and communication

$-0.87(-3.65) * * *$

Financial services

Public administration

$-1.04(-4.25)^{* * *}$

$-0.71(-3.15) * * *$

Education

$0.10(0.34)$

Health

$0.70(-3.09) * * *$

Other community services

$0.15(-0.52)$

Workplace aged $\geq 26$ years

$0.24(2.89)^{* * *}$

The proportion, if any, of the largest occupational group at this workplace work in teams

$\geq 60 \%$

$0.05(0.66)$

Pseudo R ${ }^{2}$

0.0823

Log pseudolikelihood

Prob $>\mathrm{chi}^{2}$

0.0000

$\mathrm{N}_{\mathrm{j}}$

2103

Notes: $\mathrm{z}$ statistics are in parentheses.

The reference categories are the same as Table 4 with the exception of the workplace age, which is workplace aged < 26 years since we are estimating the establishment survival since 1998 in 2005. 


\section{Notes}

1. Some studies also emphasise the union influence on workplace closure (Bryson, 2004b).

2. This paper came to light after we independently conducted our analysis of the impact training on recent establishment survival.

3. The number of observations is considerably smaller than the WERS 1998 dataset.

Details can be found in the WERS website.

4. Full details are available at www.niesr.ac.uk/niesr/wers2004.

5. This work contains statistical data from ONS which is Crown copyright and reproduced with the permission of the controller of HMSO and Queen's Printer for Scotland. The use of the ONS statistical data in this work does not imply the endorsement of the ONS in relation to the interpretation or analysis of the statistical data. This work uses research datasets which may not exactly reproduce National Statistics aggregates.

\section{APPENDIX TABLE 1}

Definitions of the variables

Variable and method of calculation

Variables used in estimations

$\boldsymbol{e}_{i j}$ : Workers years of education: converted from level of qualifications of: no qualifications (10 years); CSE/GCE/O-level (11); A-level (13); degree (16); higher degree (18). For those with additional vocational qualifications, one extra year is added.

Own Training: Workers own training: converted from periods of training of: (a) none (b) Less than 1 day (c) 1 to less than 2 days (d) 2 to less than 5 days (e) 5 to less than 10 days (f) 10 days or more. From the range of above responses from none to $\geq 10$ days, own training of less than 1 day in the last year (1) or otherwise $(0)$ was the chosen variable.

$\mathbf{E}_{\mathbf{j}}$ : Mean workplace years of education: based on percentage of the workforce in each of $k$ occupations times average years of education for that occupation from worker respondents $\left(\% \mathrm{OCC}_{\mathrm{jk}}\right) *\left(\sum \mathrm{e}_{\mathrm{ijk}} / \mathrm{n}_{\mathrm{k}}\right) \quad \mathrm{k}=1, \ldots, 9$

Mean Workplace Training: Mean workplace training: based on percentage of the workforce in each of $k$ occupations times average period of training for that occupation from worker respondents. Similar calculation as above was used. 
$\mathbf{E}_{\mathbf{j}}$ : Dispersion of workplace years of education: absolute mean difference across workers based on $\mathrm{E}_{\mathrm{i}}$

Dispersion of workplace periods of training: absolute mean difference across workers based on individual workplace training

$\boldsymbol{y}_{i j}:$ Log pay per hour per worker

$\operatorname{Ln}\{($ median pay of $m$ bands)/ (no. of hours worked) $\}, \mathrm{m}=1, \ldots, 12$.

Definitions of Other Variables used in the Regression

Variable Definition (Survey of Management Questionnaire that provides the relevant information)

Tenure: "How many years in total have you been working at this workplace? By workplace we mean the site or location at, or from, which you work.": (i) Less than 1 year (ii) 1 to less than 2 years (iii) 2 to less than 5 years (iv) 5 to less than 10 years (v) 10 years or more

Gender: “Are you male or female?": (1) Male (2) Female

Age in years: "How old are you": (i) 16-17 (ii) 18-19 (iii) 20-21 (iv) 22-29 (v) 30-39 (vi) 40-49 (vii) 50-59 (viii) 60-64 (ix) 65 or more

Ethnicity: "To which of these groups do you consider you belong?": (1) White (i) British (ii) Irish (2) Mixed (i) White and Black Caribbean (ii) White and Black African (iii) White and Asian (iv) Any other mixed background (3) Asian or Asian British (i) Indian (ii) Pakistani (iii) Bangladeshi (iv) Any other Asian background (4) Black or Black British (i) Caribbean (ii) African (iii) Any other Black background (5) Chinese or other ethnic group (i) Chinese (ii) Any other ethnic group

Disability "Do you have any long-term illness, health problem or disability?": By long-term, we mean that it can be expected to last for more than one year.": (i) Yes (ii) No.

"Does this illness or disability affect the amount or type of work you can do?": (i) Yes (ii) No Employment "Which of the phrases below best describes your job here?": (i) Permanent (ii) Temporarywith no agreed end date (iii) Fixed period-with agreed end date.

Overtime or extra hours worker whether paid or unpaid?": "How many overtime or extra hours do you usually work each week, whether: If you do not usually work overtime or extra hours please write 0 in the box below. (i) Overtime/extra hours per week (to nearest hour) paid or unpaid

Marital Status: "Which of the following describes your current status?": (i) Single(ii) Widowed (iii) Divorced/separated (iv) Married or living with a partner.

Union or staff association membership status: "Are you a member of a trade union or staff association?" : (i) Yes (ii) No, but have been in the past (iii) No, have never been a member.

Workplace size: "Currently how many employees do you have on the payroll at this establishment?"

Ratio of part-time workers/Ratio of female workers: “(a) How many of these work full-time (30 hours or more per week)? Please show males and females separately. (b) How many work part- time (fewer than 30 hours per week)? Please show males and females separately."

Of all the employees participating in the profit-related pay scheme the proportion of non-managerial employees at this workplace who received profit-related pay in the past 12 months: "What proportion of non- managerial employees at this workplace have received profit-related pay in the past 12 months?": (i) All (ii) Almost all (80-99\%) (iii) Most (60-79\%) (iv) Around half (40-59\%) (v) Some (20-39\%) (vi) Just a few (1-19\%) (vii) None $(0 \%)$

Of all the companies operating employee share schemes for employees at the workplace and 
employees who are eligible for the employee share ownership scheme(s) the proportion of nonmanagerial employees at this workplace who participate in the employee share ownership scheme(s): "What proportion of non-managerial employees at this workplace participate in the employee share ownership scheme(s)?": (i) All (ii) Almost all (80-99\%) (iii) Most (60-79\%) (iv) Around half (40-59\%) (v) Some (20-39\%) (vi) Just a few (1-19\%) (vii) None (0\%)

For how many years has this establishment been in operation? Please include time spent at other addresses: Write in number of years ' 0 ' = less than one year

The proportion of the other establishment's (sales revenue/operating costs) is accounted for by wages, salaries and other labour costs like pensions and national insurance: "About what proportion of this establishment's (sales revenue/operating costs) is accounted for by wages, salaries and labour costs like pensions and national insurance?": (i) Less than $25 \%$ (ii) $25 \%-49 \%$ (iii) $50 \%-74 \%$ (iv) $75 \%$ or more.

During the last 12 months, the number of employees who have sustained injuries: "Have any employees of this establishment sustained any of these types of injury during working hours in the last 12 months?

Proportionate change in Workplace size: The difference between workplace sizes in the 2004 and 1998 year divided by the workplace size in the 1998 year.

Proportionate change in Sectors: The difference between sectors in the 2004 and 1998 year divided by the sectors in the 1998 year.

Proportionate change in teamwork. Proportionate change in $\geq 60 \%$ team working of the largest occupational group at this workplace: The difference between $\geq 60 \%$ team working in the 2004 and 1998 year divided by $\geq 60 \%$ team working in the 1998 year.

Financial Performance when the WERS 2004 panel data is used: The variable was calculated from the following question: "Generally speaking, in establishments in your industry or field has the financial performance: (1) improved (2) stayed the same (3) or deteriorated since 1998?". "Would you say that, compared with the improvement in the average financial performance of establishments in your industry or field, your own establishments has: (1) Improved at a faster rate (2) Improved at a similar rate (3) Improved at a slower rate (4) Remained static, or (5) Actually deteriorated?

\{If financial performance stayed more or less the same\}

"Would you say that, compared with the stability in the average financial performance of establishments in your industry or field, your own workplace has ...: (1) ...improved (2) Remained stable like the rest of the industry (3) Actually deteriorated?

\{If financial performance stayed more or less the same\}

"Would you say that, compared with the deterioration in the average performance of establishments in your industry or field, the financial performance of your own workplace has... : (1) actually improved (2) ... remained stable (3) ... deteriorated at same rate as the rest of the industry, or (4) deteriorated at a faster rate than the rest of the industry? 


\section{APPENDIX TABLE 2}

Summary Statistics for the Log Pay per Hour Regression with all Variables

Education, Training and outcome variables

Mean $\begin{aligned} & \text { Standard } \\ & \text { deviation }\end{aligned}$

Education variables

Years of education per worker

$12.78 \quad 01.39$

Years of education per workplace

Interaction own-workplace education

$12.75 \quad 0.92$

$163.78 \quad 28.51$

$163.50 \quad 24.61$

Squared term: workplace education

$0.62 \quad 0.40$

Training variables

No training

$0.33 \quad 0.47$

$0.67 \quad 0.47$

Training per worker

Training per workplace

$0.66 \quad 0.33$

$0.55 \quad 0.42$

$0.54 \quad 0.38$

Squared term: workplace training

$0.24 \quad 0.13$

Dispersion of training per workplace

Other Independent variables

Worker Characteristics:

Male worker

$0.54 \quad 0.50$

Female worker

0.46

0.50

Tenure of

less than 1 year

$0.15 \quad 0.36$

1 to less than 2 years

$0.13 \quad 0.33$

2 to less than 5 years

$0.27 \quad 0.44$

5 to less than 10 years

$\begin{array}{ll}0.19 & 0.39\end{array}$

10 years or more

0.27

0.44

Age in years

16-21

$0.05 \quad 0.21$

22-29

30-39

$0.17 \quad 0.38$

$0.26 \quad 0.44$

40-49

0.27

0.44

$50-59$

0.22

0.41

60-65 or more

0.04

0.19

Ethnicity

British

0.90

0.30

Non-British

0.10

0.30

No Disability

0.95

0.05

Work-limiting disability

0.21

Employment

Permanent

$0.95 \quad 0.23$

Temporary

0.02

0.15

Fixed

0.03

0.17

Overtime or extra hours usually worked each week, whether paid or unpaid

Do not usually work overtime or extra hours

$0.46 \quad 0.50$

Overtime/extra hours per week

0.54

0.50

Marital status

Single

0.23

0.42

Widowed

0.01

Divorced/separated

$0.08 \quad 0.28$

Married or living with a partner

$0.68 \quad 0.47$

Union or staff association membership status

Union member

$0.38 \quad 0.48$

Not a union member

0.17

0.37

Firm-level Characteristics

Workplace size 
$\geq 50$ and $\leq 99$

$\geq 100$ and $\leq 499$

0.34

0.47

$\geq 500$ and $\leq 999$

0.09

0.28

$\geq 1000$ and $\leq 3999$

0.09

0.29

$\geq 4000$

0.01

0.11

Ratio of part-time workers

$0.19 \quad 0.21$

Sectors

Manufacturing

$0.19 \quad 0.39$

Electricity, gas and water

Construction

$0.06 \quad 0.24$

Wholesale and retail

$0.08 \quad 0.27$

Hotels and restaurants

0.02

0.14

Transport and communication

Financial services

$0.05 \quad 0.22$

Other business services

$0.12 \quad 0.33$

Public administration

$0.09 \quad 0.28$

Education

$0.11 \quad 0.31$

Health

$0.14 \quad 0.35$

Other community services

0.05

0.23

Of all the employees participating in the profit-related pay scheme the proportion of non-managerial employees at this workplace who have received profit-related pay in the past 12 months

All $(100 \%)$

$0.78 \quad 0.41$

Almost all (80-99\%)

0.10

0.31

Most (60-79\%)

$0.04 \quad 0.18$

Around half $(40-59 \%)$

$0.01 \quad 0.08$

Some (20-39\%)

$0.01 \quad 0.08$

Few $(1-19 \%)$

$0.01 \quad 0.09$

None $(0 \%)$

0.02

0.15

all the companies operating employee share schemes for

employees at the workplace and employees who are eligible for

$i$, the proportion of non-managerial employees at this workplace

who participate in the employee share ownership scheme(s)

All (100\%)

$0.82 \quad 0.38$

Almost all (80-99\%)

0.05

0.21

Most (60-79\%)

Around half (40-59\%)

0.02

0.13

Some (20-39\%)

0.03

0.16

Few (1-19\%)

$0.03 \quad 0.16$

None (0\%)

0.03

0.17

Ratio of female Workers

0.02

0.15

Age of workplace

Workplace aged < 20 years

0.47

0.28

Workplace older than 20 years

$0.41 \quad 0.49$

The proportion of the establishment's (sales revenue/operating costs) is

$\begin{array}{ll}0.60 & 0.49\end{array}$
accounted for by wages, salaries and other labour costs like pensions and national insurance

Less than $25 \%$

$25 \%-49 \%$

$0.21 \quad 0.40$

$50-74 \%$

0.30

0.46

$>75 \%$

$0.25 \quad 0.43$

During the last 12 months, the number of employees who have sustained Injuries

No injuries

The proportion, if any, of the largest occupational group at this workplace work in teams

$\geq 60 \%$

$0.74 \quad 0.44$

$<60 \%$

Earnings variable 


\section{REFERENCES}

Battu, H., C. R. Belfield, and P. J. Sloane (2003): "Human Capital Spillovers within the workplace: Evidence for Great Britain”, Oxford Bulletin of Economics and Statistics, 65 (5), 575-594.

Battu, H., C. R. Belfield, and P. J. Sloane (2004): "Human Capital Spillovers within the workplace: evidence for the service sector in Britain", International Journal of Manpower, 25 (1), 123-138.

Blundell, R., L. Dearden and Meghir, C. (1996): “The Determinants of Work-Related Training in Britain”, Institute for Fiscal Studies, London.

Collier, W., F. Green, and J. Pierson (2005): “Training and Establishment Survival," Scottish Journal of Political Economy, 52 (5), 710-735.

Dearden, L., H. Reed, and J. Van Reenen (2006): “The Impact of Training on Productivity and Wages: Evidence from British Panel Data," Oxford Bulletin of Economics and Statistics, 68 (4), 397-421.

Idson, T. L. and L. H. Kahane (2000): "Team Effects on Compensation: an application to salary determination in the National Hockey League," Economic Enquiry, 38, 345-357.

Kersley, B., C. Alpin, J. Forth, A. Bryson, H. Bewley, G. Dix, and S. Oxenbridge (2006): Inside the Workplace: Findings from the 2004 Workplace Employment Relations Survey. London, U.K.: Routledge.

Kremer, M. (1993): “The o-ring theory of Economic Development," Quarterly Journal of Economics, 107, 551-575. 
Lazear, E. P. (2000): “Economic Imperialism”, Quarterly Journal of Economics, 115, 99146.

Loewenstein, M. A. and J. R. Spletzer (1998): "Dividing the Costs and Returns to General Training," Journal of Labor Economics, 16, January, 142-171.

Moulton, B. R. (1987): “Diagnostics for Group Effects in Regression Analysis,” Journal of Business Economics and Statistics, 5, 272-282.

StataCorp (2003) Stata Statistical Software: Release 8.0. College Station. Texas: Stata Corporation.

Vignoles, A., F. Galindo-Rueda and L. Feinstein (2004): “The Labour Market impact of Adult Education and Training: a Cohort Analysis," Scottish Journal of Political Economy, 51 (2), 266-280.

Wolfe, B. L. and Zurekas, S. (2000): "Nonmarket Outcomes of Schooling”, International Journal of Educational Research, 27, 491-502. 